\title{
Physicochemical and Sensory Characteristics of Kawa Daun from West Sumatra at Different Smoking Time
}

\author{
Ifwarisan Defri ${ }^{1}$, Nurheni Sri Palupi ${ }^{1}$, Nancy Dewi Yuliana ${ }^{1 *}$ \\ ${ }^{1}$ Food Science Study Program, Graduate School of IPB University, Bogor 16680, Indonesia \\ *Corresponding author. Email: nancy_dewi@apps.ipb.ac.id
}

\begin{abstract}
The goals of coffee leaves pruning are for faster coffee fruit growth and an easier harvesting process. The waste of pruning coffee leaves is utilized by the native people of West Sumatra, especially in Tanah Datar to prepare local traditional beverage "Kawa Daun". The name derives from the local language "Kawa" which means brewing water from coffee leaves. The coffee leaves are dried traditionally by smoking them over a cinnamon wood fireplace for 2-6 hours. The method created a unique smell of kawa daun (aromatic smokey aroma) and a change in color, taste, and texture of the coffee leaves. Therefore, kawa daun beverage needs to be developed based on the highest level of acceptance by more diverse panelists not only those from West Sumatra but also other Indonesian provinces. The smoking time is the major factor affecting moisture content, $\mathrm{pH}$, color, and sensory characteristics of kawa daun beverage. In this research, coffee leaves were smoked for different durations $(0,2,4$, and 6 hours). The 0 -hour treatment was done by a cabinet dryer for 8 hours. The physicochemical characteristic was measured by analyzing the moisture content of powdered dry coffee leaves using oven method (wet basis), level of acidity $(\mathrm{pH})$ using a $\mathrm{pH}$ meter, the color stability using the Hunter method with CIE L*a* $\mathrm{b} *$ scale, and sensory evaluation to determine the liking level on kawa daun beverage. The panelists consisted of 65 untrained panelists from various Indonesian provinces. The results showed that the best product was the one made with 6 hours of smoking. It had moisture content of 3.04\%, $\mathrm{pH} 6.63$, color stability of $\mathrm{L}^{*}=8.81, \mathrm{a}^{*}=8.43$, and $\mathrm{b}^{*}=-14.70$. The level of acceptance for color was 4.19, aroma 4.39, taste 4.25, and overall 4.34 from 6 point scale. The Kawa daun made from 6 -hour smoked coffee leaves was had the highest acceptance score in several indicators such as blackish brewing water (color), the smell of dried coffee leaves powder (fragrance), the smell of kawa daun after brewing with boiling water (aroma), unique sense of kawa daun (taste), the combination of a unique taste and aroma (flavor), as well as a special sensation of astringent with soft bitter in the mouth and esophagus after drinking kawa daun beverages (after taste).
\end{abstract}

Keywords: physicochemical, sensory, kawa daun, smoking time, coffee leaves

\section{INTRODUCTION}

Indonesia is a fertile country, suitable for growing coffee plants. West Sumatra is one of the provinces that has high potency in growing coffee plants. Coffee leaves are pruned because they are regarded as a hindrance to growing coffee fruits. This activity is typically done by farmers to enhance the growth and to ease the harvest of coffee fruits. The local community regards pruned coffee leaves as waste and lack of economic value to be further processed. West Sumatra people, especially in Tanah Datar district, have been processing the waste of coffee leaves from Robusta coffee (Coffea canephora) into a traditional beverage called "Kawa Daun" where Kawa means brewing water from coffee leaves. Minang people have known coffee plants long before the arrival of the Dutch and at that time, the leaves were regarded as more valuable than the fruits [41].

The uniqueness of kawa daun beverage is in its way of serving. The drying of coffee leaves can be done mechanically or manually. Mechanical drying is done by small industries using a cabinet dryer equipped with a temperature controller at $70^{\circ}-90^{\circ} \mathrm{C}$ for $6-10$ hours based on the request of the customers. On the other hand, traditional manual drying is done by smoking the leaves on top of burning cinnamon wood which is aromatic and sweet. The content of phenolic substances, carbonyl substances, and acids in the smoke of the cinnamon wood affect the color, aroma, taste, $\mathrm{pH}$, and shelf life of dried coffee leaves. Because of that, cinnamon wood is suitable to be used as the fuel to smoke coffee leaves [12].

Smoking is done until the coffee leaf surface turns brown to black for 2-6 hours, as requested by the consumer, with a moisture content of $3-10 \%$ [31]. Smoking creates an aromatic smokey aroma of kawa daun beverage as well as create color, taste, and textural change of coffee leaves. The dried coffee leaves are crushed and ground into powder before brewed in water and brought to boil before consumption. $91.2 \%$ of producers still use this method of brewing with a brewing duration of 15-30 
minutes [27]. According to several kawa daun beverage sellers, this brewing method creates a kawa daun beverage with delightful aroma and taste that resembles a combination of tea and coffee, although the color of the beverage was deeper than tea but brighter than coffee [31].

Empirically, Minang people believe that kawa daun beverage provides health effects such as fitter, stronger, and warmer bodies. They stated that if they do not consume kawa daun beverage before working, they lack in strength and energy [31]. Some studies reported that the functionality of coffee leaves was due to chlorogenic acid and mangiferin content as they are the highest bioactive compounds detected in coffee leaves [10]. Other bioactive compounds in coffee leaves are mangiferin, chlorogenic acids, caffeoylquinic, caffeine, hydroxycinnamic acid, xanthine, allantoic acid, allantoin, theobromine and theophylline as well as unidentified compounds from the families of terpenoids, phenylpropanoids, flavonoids, and other alkaloids [10]. Methanolic extract of coffee leaves beverage, as analyzed by HPLC-MS, contained mangiferin, isomangiferin, epicatechin, procyanidin B1 chlorogenic acids (4 isomers), isorhamnetin glucosides, rutin glucosides, quercetin glucosides and isomers of rutin where the release of phenolic compounds depended on the temperature, around $100^{\circ} \mathrm{C}$ [2]. Robusta coffee leaves contained $27.04 \mu \mathrm{g} / \mathrm{g}$ of phenolic compounds, $10.90 \mu \mathrm{g} / \mathrm{g}$ flavonoid compounds, and condensed tannins 3.1 [26].

Kawa daun beverage contained twice trigonelline compounds than coffee beans because of partial degradation during the smoking process. A high quantity of caffeine was also found in Robusta coffee leaves as well as $0.17-4.14 \mathrm{mg} / \mathrm{g}$ (dry weight basis) of theobromine. The highest chlorogenic acid found in coffee leaves are 5-CQA and 3,5-DiCQA and their values are affected by the length of smoking through the metabolism of chemical compound degradation. Xanthones such as mangiferin and isomangiferin have never been found in any parts of coffee plants except in the leaves. Xanthone content in young coffee leaves is as high as in mango leaves. The content of 5-CQA, 3,5-DiCQAm, and mangiferin in coffee leaves proves that kawa daun beverage has antioxidant activities and strong anti-inflammatory activities [25].

Currently, kawa daun beverage is only known in West Sumatra province and small parts of the Jambi and Bengkulu provinces. However, kawa daun beverage is hoped to be more well-known not only as a part of West Sumatra local wisdom but also as the local wisdom of Indonesia. This local beverage could be further developed and distributed widely in Indonesia because of the widely available yet unused raw material from numerous coffee plantations. Because of its simple processing steps, coffee farmers could potentially develop this beverage to boost their income and create more job opportunities locally.

The potency of kawa daun beverage to be developed nationally should be directly proportional to its sensory liking. Research conducted by Finzer [13] showed that $80 \%$ of panelists preferred coffee leaves beverage compared with black tea beverage. This result showed that kawa daun beverages could potentially be accepted by the general Indonesia market, not only by West Sumatra people. However, most manufacturers still produce kawa daun beverages with inconsistent quality, therefore, to obtain a high quality and consistent kawa daun beverage, an improvement in the processing, especially during the smoking, must be made.

The optimum smoking length of time to produce the most liked kawa daun beverage has not been found. Because of that, kawa daun beverage still could not compete as a quality beverage with other beverages even though the consumers believe that it could bring health benefits. As the initial step to giving birth to high-quality local wisdom, a study on the smoking duration must be evaluated against its liking and physicochemical characteristics. This is useful to develop a kawa daun beverage that could be accepted by the general Indonesian public.

This research focused on analyzing the effect of smoking duration $(0,4,6,8$ hours $)$ towards the physicochemical and sensory attributes of kawa daun beverage. Zero-hour smoking was done using a cabinet dryer at $70^{\circ} \mathrm{C}$ for 8 hours based on the typical process done on green teas. This was done to compare whether drying without smoking could result in a better quality kawa daun beverage than smoked ones. The goals of this research were to evaluate the effect of smoking duration towards the physicochemical attributes of kawa daun beverage as well as to evaluate the acceptance of panelist towards the sensory attributes of kawa daun beverage to decide the best smoking duration that could result in the most accepted beverage and could be developed nationally.

\section{MATERIALS AND METHODS}

The raw materials for the analysis used in this study were fresh leaves of robusta coffee (C. Canephora), cinnamon wood, mineral water, and fresh bread. The chemicals used were $\mathrm{pH}$ Buffer solution of 4.0 and 7.0. The equipment used were traditional smoking furnaces, thermometer, cabinet dryer, blender, airtight plastic packaging, aluminum cup, desiccator, analytical scales, oven, $\mathrm{pH}$ meter, chromameter, plastic cup, sample label, and questionnaire sheets.

\subsection{Plant Sample Preparation}

Large, wide, and green fresh coffee leaves of robusta varieties (C. canephora), both old and young ones on the pseudostems of the coffee trees, were selected. The coffee leaves were harvested from a coffee plantation at 07.00-10.00 am then washed and sorted immediately. The coffee leaves were smoked using a smoking furnace utilizing cinnamon wood as the fuel for different durations $(0,2,4,6$ hours) while observing the temperature of the smoke. The 0-hour smoking treatment was done by drying using a cabinet dryer for 8 hours with a temperature of $70^{\circ} \mathrm{C}$. The dried coffee leaves were crushed with a blender to get a powdered kawa daun beverage. The powdered leaves were then stored in airtight plastic containers [28]. 


\subsection{Moisture Analysis}

Aluminium dishes were dried at $105^{\circ} \mathrm{C}$ for 30 minutes and cooled in a desiccator for 30 minutes before weighed (C). Three grams of samples were placed on each dish and dried in an oven at $105^{\circ} \mathrm{C}$ for five hours to reach a constant weight (B) [1]. The analysis was done in triplicate and the moisture content was reported on a wet weight basis using the following equation:

Moisture content $(\%$ wet weight basis $)=\frac{A-(B-C)}{\mathrm{A}} \times 100 \%$

\subsection{Acidity level ( $p H)$}

Brewed kawa daun beverages were conditioned to be $25^{\circ} \mathrm{C}$ in temperature and the $\mathrm{pH}$ was measured using a two-point (pH 4.0 and 7.0) calibrated $\mathrm{pH}$ meter [23].

\subsection{Color Stability}

The color measurement was done using a chromameter by Hunter method. The instrument was calibrated with a standard white plate $(\mathrm{X}=82.45 ; \mathrm{Y}=$ 84.46; $\mathrm{Z}=101.44)$. The color of the products was analyzed using CIE $\mathrm{L}^{*} \mathrm{a}^{*} \mathrm{~b}^{*}$, where $\mathrm{L}^{*}$ indicates brightness, $\mathrm{a}^{*}$ indicates green (-) to red (+) while $\mathrm{b}^{*}$ indicates blue (-) to yellow $(+)[21]$.

\subsection{Sensory Analysis}

An effective test was done to evaluate the overall liking score of brewed kawa daun beverages using 65 untrained panelists based on ASTM (American Standard Testing Material) from multiple provinces in Indonesia such as North Sumatra, West Sumatra, Jambi, Bengkulu, South Sumatra, DKI Jakarta, West Java, Central Java, East Java, South Kalimantan, East Kalimantan, South Sulawesi, and Southeast Sulawesi.

Powdered kawa daun beverage and water (1:100 ratio w/v) were heated together until boiling and the panelists were asked to evaluate their liking on the following attributes: color, aroma, taste, and overall liking based on a 6-point hedonic scale (1: dislike extremely and 6: like extremely) using the following procedures [27]:

1. $50 \mathrm{~mL}$ of each sample was placed into a randomly coded plastic cup.

2. Each panelist conducted the test in individual booths and tasted each sample personally.

3. Mineral water and fresh bread were provided as a palate cleanser.

4. The scores were recorded on the questionnaire sheet.

5. The data obtained were analyzed by analysis of variance (ANOVA) and continued with Duncan posthoc test at a significance level of $5 \%$.

\section{RESULT AND DISCUSSION}

\subsection{Moisture Content}

Based on ANOVA and DNMRT (Duncan's New Multiple Range Test) different smoking duration resulted in a significant difference in the moisture content of kawa daun powder at the confidence level of $5 \%$ as could be seen in Table 1 .

Table 1. The moisture content of kawa daun powder

\begin{tabular}{|c|c|}
\hline Smoking duration & Moisture content (\%) \\
\hline A $(0$ hour $) *$ & $3.32 \pm 0.04 \mathrm{a}$ \\
\hline B (2 hours) & $9.04 \pm 0.07 \mathrm{~b}$ \\
\hline $\mathrm{C}(4$ hours $)$ & $4.29 \pm 0.28 \mathrm{a}$ \\
\hline D (6 hours) & $3.04 \pm 1.13 \mathrm{a}$ \\
\hline
\end{tabular}

Table 1 showed that the moisture contents of kawa daun powders were not significantly different at treatment A, C, D which resulted in the moisture content of $3.32 \%$, $4.29 \%$, and $3.04 \%$ respectively. However, treatment B resulted in significantly different moisture content $(9.04 \%)$. There is no point of reference in the SNI (Indonesian National Standard) for the moisture content of kawa daun powder, therefore, the moisture content of kawa daun powder was referred to the moisture content of coffee beans (maximum of 10-13\%) and tea powder (maximum of $8-9 \%$ ). This study showed that the moisture content of kawa daun powder (3.04-9.04\%) resulted from several smoking durations managed to fulfill the moisture content of the product reference in SNI.

Both drying of coffee leaves using cabinet dryer or smoking with cinnamon wood furnace utilized hot air as the drying media. The higher the temperature and the longer the drying process would result in lower moisture content because the heat would evaporate the water in coffee leaves [36]. Cabinet drying was done by the contact between the coffee leaves and a heated metal surface and circulated with hot air that was regulated by a temperature regulator to maintain a constant temperature of $70^{\circ} \mathrm{C}$. On the other hand, smoking was done by using hot air in the form of smoke that was generated by the burning of cinnamon wood. Therefore, the air temperature was not constant with a range of $90-180^{\circ} \mathrm{C}$. Interaction between temperature and the length of drying time would affect the moisture content. The higher the temperature, the shorter the time needed to reduce the moisture content of coffee leaves [14].

Treatment $\mathrm{A}$ and $\mathrm{D}$ resulted in similar moisture content but had a tremendously different drying process. Cabinet dryer had a heater placed at one part of the oven which resulted in a less than optimum evaporation if the drying process was done for a short amount of time, on top of it the space inside a cabinet dryer was much bigger than smoking furnace [34]. Coffee leaves drying using a cabinet dryer (mechanical) at $70^{\circ} \mathrm{C}$ for 8 hours had a moisture content of $3.32 \%$, whereas to obtain similar moisture content of $3.04 \%$ by smoking required 6-hour duration at an uncontrolled temperature of $90-180^{\circ} \mathrm{C}$. However, this might not always happen because the duration of drying would be heavily influenced by rainy weather. 
Based on interviews with some kawa daun producers in Tanah Datar District, rainy weather was one of the most frequent problems they had to face during coffee leaves smoking process. Normally, the smoking process would require around 4 hours, however, the duration could be much more than that if raining occurred during the smoking process. Rain during harvesting could result in wet coffee leaves and high relative humidity around the smoking furnace which increased the moisture content of coffee leaves.

Different drying duration, both by cabinet drying and smoking not only influenced the moisture content but also other physical characteristics such as texture and color of the powdered kawa daun beverage which could be seen in Figure 1 and Table 2.

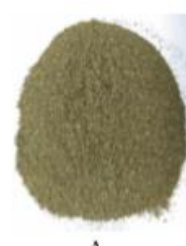

A

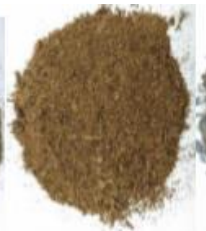

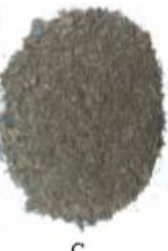

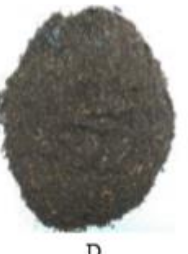

(A) Drying with cabinet dryer for 8 hours

(B) Smoking for 2 hours

(C) Smoking for 4 hours

(D) Smoking for 6 hours

Figure 1. The physical appearance of powdered kawa daun beverage

Table 2. Description of powdered kawa daun beverage

\begin{tabular}{|c|c|c|}
\hline $\begin{array}{c}\text { Smoking } \\
\text { duration }\end{array}$ & Texture & Color \\
\hline A (0 hour)* & Less dense & Dark Green \\
\hline B (2 hours) & Somewhat dense & Light Brown \\
\hline C (4 hours) & Dense & Dark Brown \\
\hline D (6 hours $)$ & Dense & Grayish Black \\
\hline
\end{tabular}

(*)Drying with cabinet dryer for 8 hours

Table 2 explained that the 2-hour smoking process resulted in somewhat dense powdered kawa daun beverage, whereas smoking for 4 and 6 hours at temperature reaching $180^{\circ} \mathrm{C}$ resulted in a dense powder. On the other hand, drying with a cabinet dryer for 8 hours resulted in a less dense powder compared to other treatments. Drying with a cabinet dryer that used convectional heat transfer using an electric stove where the heat energy was transferred by air that was blown by a blower to evaporate the water inside the leaves. Allegedly, this process required a long time to evaporate the physically and chemically bound water because the heat only passed through part of the surface material which resulted in the expansion of the material and created cavities between the powder particles [34].

As could be seen in Figure 1 and Table 2, the longer the smoking duration, the more damage was done towards the pigment in coffee leaves. Treatment B, C, and $\mathrm{D}$ transformed the color of green coffee leaves into light brown, dark brown, and grayish-black respectively. However, treatment A managed to maintain part of the chlorophyll pigment in the coffee leaves that resulted in a dark green kawa daun powder. This was the main advantage of a cabinet dryer that utilized lower and more constant temperature compare to the smoking process which prevented excessive pigment damage and resulted in green coffee leaves [34].

According to Miazek [24], the green color in coffee leaves comes from chlorophyll which is located in the intracellular lamellar organelles called the chloroplast. Its existence is protected by a protein that forms a chlorophyll-protein complex. This complex is surrounded by a protein-lipid bilayer that stabilizes the chlorophyll inside the organelles. Chlorophyll binds to $\mathrm{Mg}$ ion in the center and has a fifth isocyclic ring that is located near the third pyrrole ring. On the fourth ring, substituents propionic acid was esterified with a hydrophobic phytol group [20].

Chlorophyll is easily degraded by heat which resulted in lost green color because it has been transformed into its derivative compounds. The processing of coffee leaves with smoking denatured the protein inside the chlorophyll-protein complex and formed pheophytin which is another form of chlorophyll that lacks its original green color because the $\mathrm{Mg}$ ion has been lost and transformed into a hydrogen ion [30]. The drying process of coffee leaves unbind the $\mathrm{Mg}$ ion from the chlorophyll and followed by the unbinding of the phytol group (dephytylation) [20]. There are two kinds of chlorophyll, chlorophyll (a) and chlorophyll (b). Chlorophyll (a) owns a methyl group, is less polar and is bluish-green whereas chlorophyll (b) owns a formyl group, is polar, and is yellowish-green in color [32]. The color transformation of coffee leaves from green into brown and grayish-black is allegedly caused by the transformation of bluish-green chlorophyll (a) into gray pheophytin (a) and the transformation of yellowish-green chlorophyll (b) into a brown pheophytin (b) [20].

Wood smoke could also function as the coloring agent of coffee leaves where the new color could be formed upon contact of the coffee leaf surface with the cinnamon bark smoke. The color formation could also happen when the smoke and certain compounds in the coffee leaves react chemically. The ability of wood smoke to color materials is associated with carbonyl compounds. The longer the smoking process, the darker the coffee leaves. This was caused by the high content of carbonyl compounds resulted from the burning of cinnamon wood. The higher the carbonyl compounds, the darker the generated color [8]. Color formation in smoked products was also caused by the Maillard reaction. As the products are heated, the carbonyl compounds react with the protein inside the materials that caused Maillard reaction to occur and produce a brownish to blackish colored coffee leaves powder [38]. 


\subsection{Acidity $(p H)$}

Based on the results of the analysis of variance (ANOVA) and Duncan's New Multiple Range Test (DNMRT), differences in the duration of smoking yield to significantly different $\mathrm{pH}$ levels of kawa daun beverages at the confidence level of $\alpha=5 \%$, as could be seen in Table 3.

Table 3. The acidity $(\mathrm{pH})$ of kawa daun beverage

\begin{tabular}{|c|c|}
\hline Smoking duration & $\mathrm{pH}$ \\
\hline A (0 hour)* & $5.56 \pm 0.09 \mathrm{a}$ \\
\hline B (2 hours) & $5.78 \pm 0.03 \mathrm{~b}$ \\
\hline C (4 hours) & $6.38 \pm 0.06 \mathrm{c}$ \\
\hline D (6 hours) & $6.63 \pm 0.15 \mathrm{~d}$ \\
\hline
\end{tabular}

(*)Drying with cabinet dryer for 8 hours

$( \pm)$ Standard Deviation

The principle in the assessment of acidity $(\mathrm{pH})$ using a $\mathrm{pH}$ meter is based on the measurement of hydrogen ions as measured by its potentiometry/electrometry using a $\mathrm{pH}$ meter. Before each use, the $\mathrm{pH}$ meter is calibrated with a buffer solution according to the equipment instructions for each measurement [9]. In principle, the lower the $\mathrm{pH}$ the higher acidity a product will have and vice versa [39]. The increase in $\mathrm{pH}$ of kawa daun beverage can be seen in Figure 2.

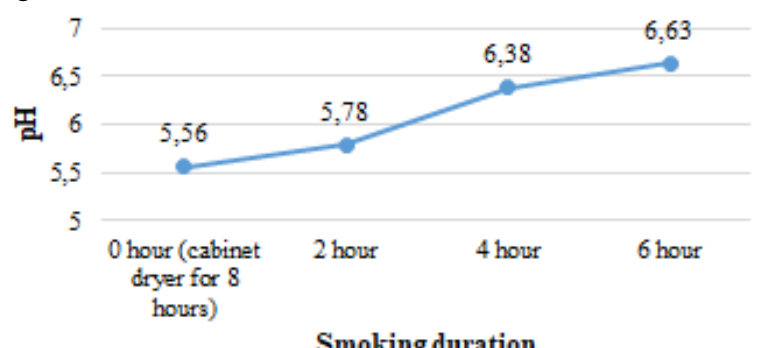

Figure 2. The increase in $\mathrm{pH}$ of kawa daun beverage

Based on Table 3 and Fig. 2 the pH of kawa daun beverages from treatment A, B, C, and D were 5.56, 5.78, 6.38 , and 6.63 respectively. This showed that the longer smoking duration would result in a significant increase in the $\mathrm{pH}$ of kawa daun beverage. All treatments yielded acidic beverages as the $\mathrm{pH}$ levels were less than 7. Cabinet dried kawa daun beverage resulted in the most acidic beverage, whereas 6-hour smoked kawa daun beverage yielded a close to neutral $\mathrm{pH}$.

The acidity of kawa daun beverage was caused by the smoking process. This was allegedly caused by the degradation of caffeine as one of the components in kawa daun beverage into xanthine. Based on the previous study by Khotimah [22], the caffeine content of variously aged Robusta coffee leaves was $0.12-1.15 \%$. Long crystalshaped caffeine is white like silk and has a bitter taste. Caffeine functions as a compound that brings forth taste and aroma. Caffeine content that could alter the $\mathrm{pH}$ of coffee leaves is affected by the variety of coffee leaves, growing location, and its processing steps. Caffeine is continuously produced inside the coffee leaves until the leaves reach their maximum age [5].

The mechanism of caffeine degradation of coffee leaves according to Ashihara [5] states the xanthine of caffeine is derived from purine nucleotides. Initially, Xanthine is present at a much lower concentration (0.07$\left.0.22 \mathrm{mg} \mathrm{g} \mathrm{g}^{-1}\right)$ than caffeine (5.7-7.1 $\left.\mathrm{mg} \mathrm{g}^{-1}\right)$. The cause of its slow degradation is the removal of three methyl groups to produce the formation of xanthine. Xanthine is then degraded by catabolism pathways conventional purine into $\mathrm{CO}_{2}$ and $\mathrm{NH}_{3}$ through uric acid, allantoin, and allantoate. Xanthine has a pKa of 7.7, much higher than pKa of caffeine at 0.8 . Higher $\mathrm{pH}$ shows that it has a more basic property. In principle, the higher the $\mathrm{pKa}$ value of a compound will result in a higher $\mathrm{pH}$ [37]. Because of that, as caffeine is broken down into xanthine that has higher $\mathrm{pKa}$ than caffeine, the $\mathrm{pH}$ of kawa daun beverage of kawa daun will increase as well [11].

Two-hour smoking treatment and cabinet drying treatment yielded the lowest $\mathrm{pH}$ kawa daun beverage. Allegedly, during those treatments, the caffeine was only degraded into uric acid [16]. As more caffeine was broken down into uric acid, therefore uric acid content would be higher than the content of xanthine which would decrease the $\mathrm{pH}$ of kawa daun beverage [11]. In the absence of the smoking process, it is proposed that caffeine degradation is not significant because of the constant temperature of $70^{\circ} \mathrm{C}$, therefore cabinet drying process could maintain the chemical compound contents of dried goods [34].

Based on the $\mathrm{pH}$ recommendations from the Quick Reference Food Charts, food $\mathrm{pH}$ should be between 4 to 9 . As could be seen from table 3 and figure 2, the $\mathrm{pH}$ of kawa daun beverages was in the recommended range. The $\mathrm{pH}$ value of kawa daun beverage would contribute to its shelf life and sensorial characteristics [11].

\subsection{Hedonic Test}

Sensory evaluation by hedonic scale rating is an evaluation method using all five senses, especially eyes, nose, and mouth. Through these senses, the panelists could rate the sensory attributes of a product such as color, shape, aroma, and taste [19]. Hedonic evaluation on kawa daun beverage was done using acceptance using many panelists to reveal the liking towards it. The hedonic scale showed the liking score of panelists. The preparation and serving of kawa daun beverages during the test were done at a constant temperature and quantity as well as randomly coded [27].

This test was done using 65 untrained panelists from multiple provinces in Indonesia such as North Sumatra, West Sumatra, Jambi, Bengkulu, South Sumatra, DKI Jakarta, West Java, Central Java, East Java, South Kalimantan, East Kalimantan, South Sulawesi, and Southeast Sulawesi so that the test could be more comprehensive and representative in terms of consumer backgrounds as kawa daun beverage was targeted to not only be a local West Sumatra product but also a nationally accepted product. As could be seen in Figure 3, most panelists were not aware of the kawa daun beverage. 


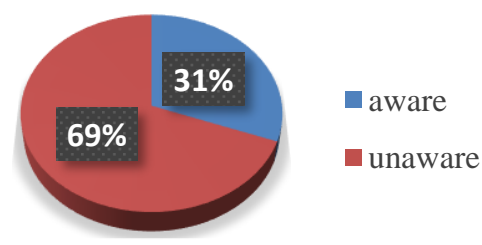

Figure 3. Panelists' awareness of the product

As could be seen from the above diagram, $69 \%$ of the panelists were unaware of kawa daun beverage. Panelists who were unaware of the product came mostly from outside of West Sumatra whereas the panelists with product awareness came from West Sumatra, Jambi, Bengkulu and some from Java.

The uniqueness of kawa daun flavor came from the smoking process utilizing cinnamon wood that produced cinnamon aromatic smokey flavor. Smoking of coffee leaves would also chemically alter the compositions in kawa daun beverage as well as taste, aroma, and color of the brewed beverage. Smoked coffee leaves experienced chemical alterations that produced delightful flavor [19]. The liking score of kawa daun beverage towards four different attributes can be seen in Table 4 and a more descriptive presentation of the data from sensory evaluation in the form of a spider chart can be seen in Figure 4.

Table 4. Kawa daun beverage liking score

\begin{tabular}{|c|c|c|c|c|}
\hline Smoking duration & Color & Aroma & Taste & Overall \\
\hline A (0 hour)* & $3.92 \pm 1.41 \mathrm{a}$ & $3.77 \pm 1.20 \mathrm{a}$ & $3.40 \pm 1.13 \mathrm{a}$ & $3.57 \pm 0.98 \mathrm{a}$ \\
\hline B (2 hours) & $4.14 \pm 1.07 \mathrm{a}$ & $3.82 \pm 1.00 \mathrm{a}$ & $3.59 \pm 1.16 \mathrm{a}$ & $3.79 \pm 1.07 \mathrm{ab}$ \\
\hline C (4 hours) & $4.28 \pm 1.07 \mathrm{a}$ & $4.22 \pm 1.10 \mathrm{a}$ & $4.10 \pm 1.27 \mathrm{~b}$ & $4.12 \pm 1.13 \mathrm{~b}$ \\
\hline D $(6$ hours $)$ & $4.19 \pm 1.22 \mathrm{a}$ & $4.39 \pm 1.16 \mathrm{a}$ & $4.25 \pm 1.36 \mathrm{~b}$ & $4.34 \pm 1.17 \mathrm{~b}$ \\
\hline
\end{tabular}

(*)Drying with Cabinet Dryer for 8 hours

$( \pm)$ Standard Deviation

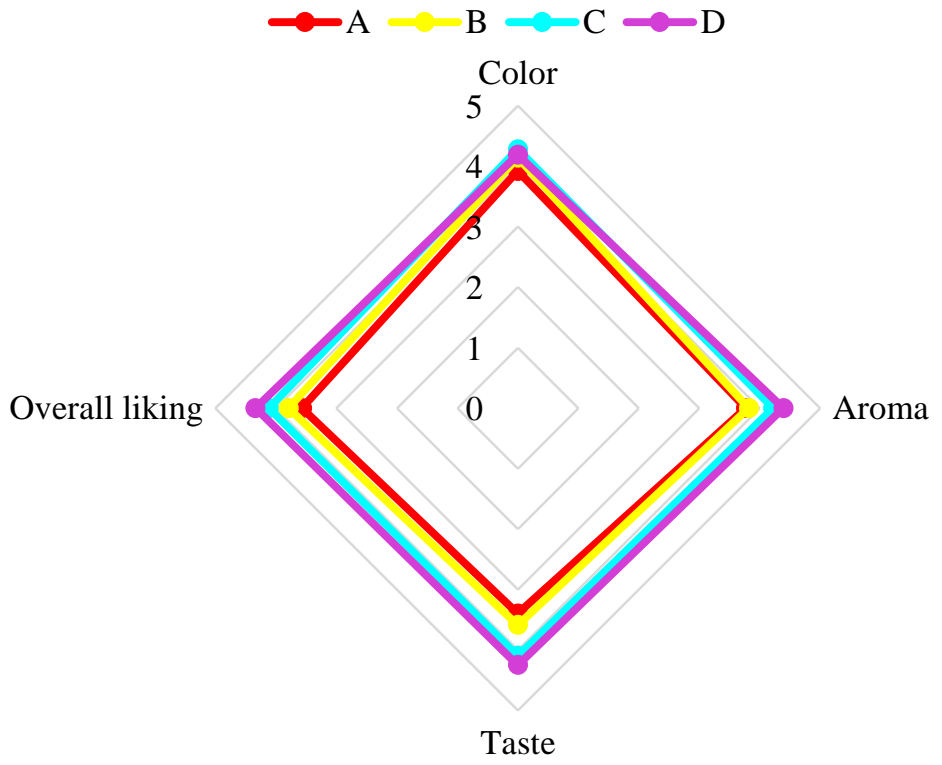

\subsubsection{Color}

Color played an important role in the acceptance of a product visually. A visually unappealing and off-colored food product would not be accepted by consumers even though it has a delightful flavor. Consumers will determine the quality of a product firstly by its color because it is the initial impression that could be seen by consumers [40]. Color also indicates the taste of a food product even though the color might not always be identical to the taste. Deviation in the color of food products from the generally available ones would result in consumer rejection even

\section{score of kawa daun beverage}

though they are perfectly safe to consume [6]. During the product evaluation session, the color is used as a benchmark of the quality attribute, identity, and consumer appeal. The color will affect the consumers to accept or reject food products [27].

Based on Table 4 and Fig. 4, the panelists gave the highest liking score towards color on treatment $\mathrm{C}$ (4-hour smoking) with an average score of 4.28 and followed by treatment D, B, and A with a score of $4.19,4.14$, and 3.92 respectively. Statistically speaking, the color liking score on treatment $\mathrm{C}$ was not significantly different compared to 
those on treatment A, B, and D. Allegedly, each treatment resulted in an exceptionally different color with their distinctive color characteristics that were influenced by the smoking duration. Each panelist has their perception and assumption towards the colors of each treatment which might cause the inclination of panelists to give similar scores to all treatments. The color difference of brewed kawa daun beverage could be seen in Fig. 5 .

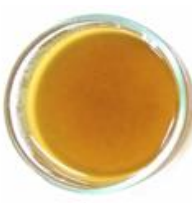

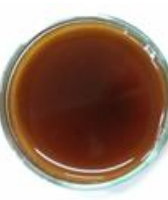

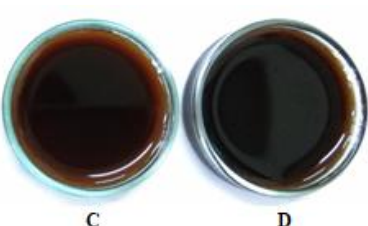

(A) Drying with cabinet dryer for 8 hours

(B) Smoking for 2 hours

(C) Smoking for 4 hours

(D) Smoking for 6 hours

Figure 5. The color difference of brewed kawa daun beverage

As could be seen in Fig. 5, the color of brewed kawa daun beverages was heavily influenced by the duration of smoking. The shorter the smoking duration of coffee leaves, the brighter the liquid from brewing kawa daun powder and vice versa. The brightest color was owned by treatment A (drying with cabinet dryer for 8 hours or no smoking). On the other hand, the darkest color was owned by treatment D (6-hour smoking). The color description of each brewed kawa daun beverage could be seen in Table 5.

Table 5. Color description of brewed kawa daun beverage

\begin{tabular}{|c|c|}
\hline Smoking duration & Color \\
\hline A (0 hour)* & Golden yellow \\
\hline B (2 hours) & Reddish Brown \\
\hline C $(4$ hours $)$ & Dark brown \\
\hline D $(6$ hours $)$ & Black \\
\hline
\end{tabular}

(*)Drying with Cabinet Dryer for 8 hours
Based on Table 5, treatment A, B, C, and D tended to produce variously colored brewed kawa daun beverages, golden yellow, reddish-brown, dark brown, and black respectively. The color from each treatment resulted in its distinctive color and appeal which cause the lack of significant difference in the color liking score. Four-hour and six-hour smoking treatment resulted in beverages with darker color compared to 8-hour drying and 2-hour smoking treatment.

Table 4 and Table 5 summarize the descriptive result based on the questionnaire assessment of the color attribute of brewed kawa daun beverages according to the assumption and perception of 65 panelists subjectively. There was no significant difference between all treatments statistically in terms of the liking score of brewed beverages. This could happen because of the panelists' condition of senses. Human-based panelists sometimes have certain physical and mental conditions that could cause saturation in tasting and decrease in sensory sensitivity, therefore it was imperative to ensure the panelists were in healthy condition. Generally speaking, all samples were well accepted by the panelists with an average liking score of 4-5 (quite like - like). Panelists have their perceptions and assumption when giving subjective scores. To reduce the error in color analysis, color stability analysis using chromameter was conducted to describe the colors of brewed kawa daun beverage objectively [27].

\section{Color analysis using chromameter CIE ( $\left.L^{*} a^{*} b^{*}\right)$}

Assessment by human panelists tended to be subjective because of the use of visual senses, therefore an objective analysis using chromameter CIE $\mathrm{L}^{*} \mathrm{a}^{*} \mathrm{~b}^{*}$ was needed to obtain more objective measurements in differentiating each brewed kawa daun beverage samples. The result of the measurements with chromameter instruments could be seen in Table 6 .

Table 6. Color analysis with chromameter (CIE L*a*b*)

\begin{tabular}{|c|c|c|c|}
\hline Smoking duration & $\mathrm{L}^{*}$ & $\mathrm{a}^{*}$ & $\mathrm{~b}^{*}$ \\
\hline A (0 hour)* & $22.01 \pm 2.28 \mathrm{c}$ & $11.59 \pm 0.84 \mathrm{~b}$ & $10.10 \pm 2.03 \mathrm{c}$ \\
\hline B (2 hours) & $11.68 \pm 0.84 \mathrm{~b}$ & $9.25 \pm 1.46 \mathrm{a}$ & $-10.04 \pm 1.60 \mathrm{~b}$ \\
\hline C (4 hours) & $9.59 \pm 0.11 \mathrm{a}$ & $8.55 \pm 0.12 \mathrm{a}$ & $-13.47 \pm 0.09 \mathrm{a}$ \\
\hline D (6 hours) & $8.81 \pm 0.22 \mathrm{a}$ & $8.43 \pm 0.44 \mathrm{a}$ & $-14.70 \pm 0.44 \mathrm{a}$ \\
\hline
\end{tabular}

(*) Drying with Cabinet Dryer for 8 hours

$( \pm)$ Standard Deviation

The colors of kawa daun beverage made with different smoking duration were measured with CIE $\mathrm{L}^{*} \mathrm{a}^{*}$ $b^{*}$ method. The $L^{*}$ value ranges from 0 to 100 , where a higher score indicating lighter color and a lower score indicating darker color. A positive $a^{*}$ value indicates red color whereas a negative value indicates green color. A positive $b^{*}$ value indicates yellow color whereas a negative value indicates blue color [3].

Based on Table 6, it could be seen that treatment A had the highest $\mathrm{L}^{*}$ value of 22.01 whereas treatment $\mathrm{D}$ had the lowest $\mathrm{L}^{*}$ value of 8.81 indicating that treatment A resulted in the lightest color and treatment $\mathrm{D}$ resulted in 
the darkest color of brewed kawa daun beverage even though treatment $\mathrm{C}$ and $\mathrm{D}$ did not have a significant difference in terms of $\mathrm{L}^{*}$ value. The $\mathrm{a}^{*}$ value from all treatments resulted in positive values indicating that the colors of brewed kawa daun beverages were reddish. The highest $\mathrm{a}^{*}(+)$ value was owned by treatment A (11.59) whereas the lowest $\mathrm{a}^{*}(+)$ was owned by treatment D (8.43). However, there was no significant difference in terms of $\mathrm{a}^{*}$ between treatment $\mathrm{B}, \mathrm{C}$, and $\mathrm{D}$. This result showed that the brewed kawa daun beverage from treatment $\mathrm{A}$ had the most reddish color compared to those from treatment $\mathrm{B}, \mathrm{C}$, and $\mathrm{D}$ which had slightly reddish color. Treatment A resulted in the highest $\mathrm{b}^{*}(+), 10.10$, indicating that treatment $\mathrm{A}$ yielded to a yellowish colored beverage. Negative $b^{*}(-)$ values were apparent at beverages from treatment $\mathrm{B}, \mathrm{C}$, and $\mathrm{D}$ with treatment $\mathrm{D}$ had the lowest value, 14.70. This indicated that B, C, and $\mathrm{D}$ had brewed kawa daun beverages that were more bluish, even though there was no significant difference in the results of treatment $\mathrm{C}$ and $\mathrm{D}$.

The colors of kawa daun beverage made by different smoking duration were typically yellow, brown, or black. The longer the smoking duration would result in darker colored beverages. Lower $\mathrm{L}^{*}$ value indicated brownish yellow to black color which was caused by $1.45 \%$ of phenolic and carbonyl compounds produced by smoke and enzymatic reaction during the brewing step. The difference in smoking duration allegedly determined the color of brewed kawa daun beverage, the longer the smoking duration, the more damage was done on the pigments turning the color of coffee leaves into brown to black [34].

The temperature during the smoking process was not constant with longer smoking duration resulted in higher temperatures causing darker colored brewed kawa daun beverage. Several high-temperature treatments applied to kawa daun beverages such as drying, smoking, and brewing would degrade the polyphenols and darken the color of the brewed beverage. High-temperature processing on kawa daun beverages would increase the rate of oxidation in the products and darken the brewed kawa daun beverage [36].

According to Ratanamarno [33], the catechin content of fresh coffee leaves was $0.05-0.18 \mathrm{mg} / \mathrm{g}$. During the smoking process, catechin would be transformed into simpler compounds such as flavonoid polyphenols which in turn giving the distinctive color of the brewed kawa daun beverage [36]. Thermal processes such as brewing and smoking would also stimulate Maillard browning reaction between the protein, amino acids, trigonelline, and serotonin with the carbohydrates, hydroxylic acids, and phenolic compounds within the coffee leaves [15].

According to Bello [7], there is a correlation between the $\mathrm{pH}$ and the color of the brewed kawa daun beverage. The transformation of the green color in coffee leaves is due to $\mathrm{pH}$-influenced chlorophyll conversion into pheophytins where higher temperature processing would cause hydrogen ions to alter chlorophyll into pheophytin by replacing magnesium ion inside the porphyrin ring.
Chlorophyll conversion into pheophytin and pheophorbide transforms bright green color from chlorophyll into a dark green then into yellow and finally into brown and black.

Elevation in temperature could also increase the number of ions inside the solution because of molecule dissociation (especially true for weak acid and weak base). Chlorophyll stability is known to be influenced by $\mathrm{pH}$. The $\mathrm{pH}$ in green coffee leaves during the thermal process is not constant. The amount of $\mathrm{pH}$ change depends on the type of coffee leaves, initial $\mathrm{pH}$, heating duration (during smoking and brewing), smoking temperature (wether with elevated temperature and short time or low temperature and long time). Dark brown and black brewed liquid from 4-hour and 6-hour smoking treatment could be caused by high $\mathrm{pH}$ that removed magnesium ion from chlorophyll [7].

\subsubsection{Aroma}

Based on Table 4 and Fig. 4, the panelists gave the highest aroma liking score of 4.39 to kawa daun beverage from treatment $\mathrm{D}$ (6-hour smoking duration) followed by treatment $\mathrm{C}, \mathrm{B}$, and $\mathrm{A}$ with scores of $4.22,3.87$, and 3.77 respectively. However, there was no significant difference between all treatments which could be caused by the distinct aroma resulting from the various smoking process. The longer the smoking duration would increase the distinct aroma of kawa daun beverage. Kawa daun beverage from treatment A yielded the lowest aroma liking score. It was presumed that cabinet drying for 8 hours was not optimal to evoke the unique aromatic smokey aroma of kawa daun beverage as the smoking process was the main formation phase to produce the unique flavor of kawa daun beverage [29].

Wood smoke is an aerosol generated from burning wood at elevated temperatures. The smoke composition will vary depending on the type of wood used in the burning process. There are more than 400 identified aroma compounds in wood smoke with 40 acids, 22 alcohols, 131 carbonyl compounds, 22 esters, 46 furans, 16 lactones, and 75 phenolic compounds have been identified. Cinnamon wood also contains essential oils or oleoresins that contain chemical compounds such as cinnamaldehyde, eugenol, methyl ketene, furfural, benzaldehyde, nonyl aldehyde, hydrocinnamic aldehyde, cumin aldehyde, and coumarin which could give cinnamon wood smoke the unique cinnamon aroma that could be transferred into the materials being smoked [12].

Coffee leaves naturally contain numerous organic compounds that could act as precursors in creating the unique flavor and aroma of coffee leaves. The changes in physical and chemical attributes that could happen during smoking are as follows: swelling, water evaporation, the formation of volatiles, caramelization, decomposition of crude fibers, protein denaturations, formation of $\mathrm{CO}_{2}$ from oxidation, and formation of unique coffee leaf aroma. Smoking would also emit gases such as $\mathrm{CO}_{2}$ which could fill the space between the cells or the pores of coffee leaves. Coffee leaves contain similar flavor precursor compounds with coffee beans, even though in much lower concentrations, such as nonvolatile phenolic and acids 
such as acetaldehyde, propanone, alcohol, vanillin aldehyde; acidic carbonyl compounds such as oxalosuccinate, acetoacetate, hydroxy pyruvate, ketone, caproate, oxalacetate, mesoxalate, and mercaptopyruvate; amino acids such as leucine, isoleucine, valine, hydroxypyroline, alanine, threonine, glycine, and aspartic acid, as well as volatile acidic compounds such as acetic acid, propionic acid, butyric acid, and valeric acid. Some parts of caffeine would also evaporate and form decompose into compounds such as acetone, furfural, ammonia, trimethylamine, formic acid, and acetic acid during the smoking process [15].

Treatment $\mathrm{D}$ resulted in a kawa daun beverage that had the strongest cinnamon-like aroma. This aroma came from phenolic compounds in the cinnamon wood smoke. Phenolic compounds came from the disintegration of wood particles such as lignin. The higher the lignin content in the wood, the higher the content of phenolic compounds in the generated smoke. The content of phenolic compounds in the cinnamon wood smoke range from 0.2-2.9\% [8]. Other factors affecting the aroma of kawa daun beverage was the grinding process using a blender to obtain a coffee leaf powder called kawa daun. Kawa daun powder has a larger surface area compared to the whole leaves, because of that, the aromatic compounds would dissolve more easily during the brewing process. Smoking duration and temperature were the most important part in the formation of kawa daun aroma. The longer the smoking duration with high heat would quickly evaporate the volatile compounds, therefore the original aroma could still be retained compared with the cabinet drying process [34].

\subsubsection{Taste}

Based on Table 4 and Fig. 4, panelists gave the best taste liking score with an average of 4.25 towards kawa daun made through treatment $\mathrm{D}$ (6-hour smoking) and followed by treatment $\mathrm{C}, \mathrm{B}$, and A with average scores of 4.10, 3.59, and 3.40. Statistically speaking, there was no significant difference between treatment $\mathrm{A}$ and $\mathrm{B}$ as well as between treatment $\mathrm{C}$ and $\mathrm{D}$. Each panelist has their perception and liking towards the taste of each treatment process. Treatment A (cabinet drying) resulted in the lowest taste liking score compared with other treatments. This might have been caused by the lack of kawa daun unique aroma from the drying process. The longer smoking process would increase the drying temperature reaching $180^{\circ} \mathrm{C}$ which would impart a strong smokey aroma in kawa daun beverage [29]. Distinct kawa daun taste is influenced by over-smoked coffee leaves and creating a more delicious kawa daun beverage [36].

According to the results of a survey to 65 panelists regarding the sensations and perceptions of kawa daun beverage, treatment A beverage had more fresh leaf aroma, green aromatic, sharp astringent, slightly sweet, leafy, viney, unripe, grassy, fresh, raw, sharp, roasted. Treatment B had a combination of somewhat sweet, somewhat sour, astringent, a hint of cinnamon, woody, heavy impression, lightly sweet, lightly green, and slightly bitter. Treatment $\mathrm{C}$ had a combination of sweet, slightly acidic, slightly astringent, bitter, strong cinnamon-scented, brown, fruity, sweet, blended scent impression. Treatment $\mathrm{D}$ had a combination of sweet, soft bitter, sour, slightly astringent, strong cinnamon aroma, sweet aromatic impression, floral aromatic, thickness, astringent mouthfeel, burnt, smokey, ashy, longevity and fullness. Most panelists stated that D treatment had the most unique and distinct taste.

Based on Handayani [18], off-flavor characteristics that must be avoided in beverages such as coffee, tea, and similar beverages were stinky, earthy, moldy, musty, sour, oily and chemical flavor. When the statement from Handayani [18] was compared with the descriptions of kawa daun beverages, none of the treatments had such offflavor descriptions. Therefore, it could be concluded that all treatments were free of off-flavor while possessing unique and distinct taste because of different smoking duration.

Coffee leaves have a quite high concentration of caffeine which is a compound generated from the secondary metabolism of alkaloids in coffee plants and has a bitter taste. Caffeine would impart distinct bitter flavor in coffee leaves. The caffeine content in various age coffee leaves was in the range of $0.12 \%-1.15 \%$ [22]. The difference in smoking would alter tannin concentration where the higher the temperature and the longer the smoking process, the lower the tannin concentration would be because the tannins would be degraded into simpler compounds. This explains why 6-hour smoked kawa daun beverage had the highest liking score because it was not too astringent and had a balanced flavor [36].

Cinnamon wood smoke has a high concentration of phenolic compounds and the generated flavor would be influenced by the concentrations of the components inside the smoke. Cinnamon wood smoke would trigger a sensory response of taste and kresolik at high concentrations while tasting sweet at suitable concentrations [38]. Cinnamon wood smoke yielded a kawa daun beverage with a pleasant aromatic smokey flavor [4]. Allegedly, the long smoking process-induced an interaction between the coffee leaves and the smoke, giving kawa daun beverage its strong flavor, therefore reducing the leafy aroma in 6-hour smoked kawa daun beverage.

\subsubsection{Overall liking}

Based on table 4 and Fig 4, panelists gave the best overall liking score of 4.34 towards kawa daun from treatment $\mathrm{D}$, followed by treatment $\mathrm{C}, \mathrm{B}$, and $\mathrm{A}$ with average scores of $4.12,3.79$, and 3.57 respectively. However, there was no significant difference between the scores of treatment $\mathrm{C}$ and $\mathrm{D}$. Treatment $\mathrm{A}$ had the lowest liking score in all attributes (color, aroma, taste, and overall liking). The panelists gave the highest liking score of aroma, taste, and overall liking attributes to the beverage from treatment $\mathrm{D}$ while the highest liking score in terms of color to treatment $\mathrm{C}$. This led to a conclusion that treatment D (6-hour smoking) was the most liked and accepted treatments based on the attributes that have been agreed by the panelists. Acceptance attribute is a very 
important attribute in terms of product acceptance of a product before being launched to the market [27]. The panelists chose that kawa daun beverage from treatment $\mathrm{D}$ was the most accepted based on all attributes to be marketed. The survey result of 65 panelists in regards to the most liked kawa daun beverage could be seen in Fig. 6 .

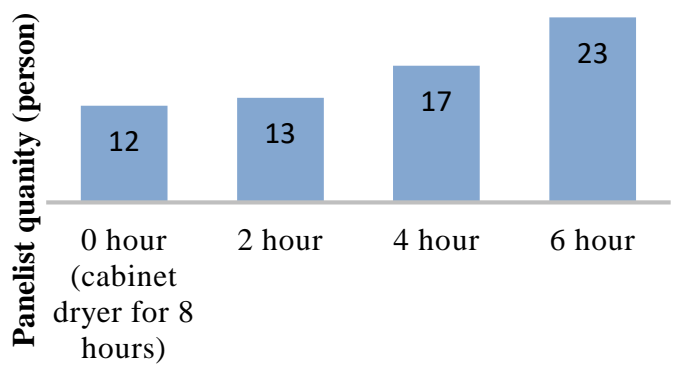

Smoking duration (hour)

Figure 6. The most liked kawa daun beverage

The panelists' assumptions and perceptions towards color, aroma, taste, and overall attributes of kawa daun beverage vary from each other. Based on the survey result of 65 panelists from various provinces in Indonesia showed that 23 random panelists from North Sumatra, West Sumatra, Bengkulu, DKI Jakarta, West Java, East Java, East Kalimantan, and Southeast Sulawesi preferred kawa daun beverage from treatment D, 6-hour smoking. A total of 17 random panelists from West Sumatra, Bengkulu, DKI Jakarta, West Java, Central Java, South Kalimantan, and South Sulawesi preferred the beverage made by treatment C, 4-hour smoking. A total of 13 random panelists from Jambi, South Sumatra, South Kalimantan, and West Java preferred the beverage made by treatment B, the 2-hour smoking. Finally, a total of 12 random panelists from Central Java, South Sulawesi, and DKI Jakarta favored the beverage made by treatment A, namely 0 -hour smoking or drying for 8 hours with cabinet dryer.

Based on observational interview and questionnaire guided discussion with 5 random producers of kawa daun beverage located in Tanah Datar and Agam District, West Sumatra in regards to the typical and traditional smoking duration in January 2020, most producers at Agam District conducted the smoking process for 2 and 4 hours rather than 6 hours. This was done because Agam District producers put a lot of consideration into the time efficiency and fuel cost during the production since cinnamon wood was hard to obtain and expensive. On the other hand, most Tanah Datar producers and some Agam District producers conducted the smoking process for 6 hours to obtain the sensory characteristics most liked by the West Sumatra consumers.

During special occasions such as weddings, circumcision celebrations, or other traditional events, most consumers specially requested kawa daun that has been smoked at a longer duration (6 hours). This showed that each consumer has their preferences of kawa daun flavor since the longer the smoking process would impart some advantages in terms of the fragrance of kawa daun powder, the aroma of brewed kawa daun, the thickness body of kawa daun beverage, the unique flavor of kawa daun, and the soft bitter astringent aftertaste [31].

Cinnamon wood smoke imparts color, taste, and aroma naturally to kawa daun beverage. More than 400 chemical compounds have been identified in wood smoke where most compounds were formed by the pyrolysis of three main wood components, namely cellulose, hemicellulose, and lignin. The smoke generated from starch or wood lignin is very abundant in carbonyl compounds, therefore, the smoke could act as a browning agent and accelerator of grilled color. Phenolic compounds, carbonyl compounds, and acids in cinnamon smoke could affect the color, aroma, taste, $\mathrm{pH}$, and shelf life of food products. Based on the research by Budaraga [9], the phenolics content in liquid cinnamon wood smoke was $2.49 \%$ and the carbonyl content was $4.97 \%$. Cinnamon wood smoke contained carbonyl compounds that react with proteins in the coffee leaves to generate the brownish color and phenolic compounds which were the main source of its aroma and imparted antioxidant activities as well [12].

The taste and aroma of smoke are Generally Regarded as Safe (GRAS) according to USDA and FDA since it is natural occurring taste and aroma. The knowledge of wood smoke content has helped food industries to produce functional flavors through interaction between the food nutritional contents and the smoke utilized during the processing. Taste and aroma are products of complex interactions between those various compounds. The unique taste and aroma of wood smoke are mainly due to the phenolic compounds that have been used to measure the intensity of smoked taste and aroma [38].

The role of cinnamon wood smoke as a natural preservative has been widely known. Some natural compounds specific to cinnamon wood smoke had antibacterial and antifungal activities. (E)cinnamaldehyde (essential oil) and proanthocyanidins (polyphenols) were the main contents of herbal oil from cinnamon bark that possess antibacterial activities [35]. The cinnamon essential oil contains cinnamaldehyde and cinnamic acid that are effective in retarding the growth of some bacteria species such as B. cereus, S. aureus, E. coli, $P$. aeruginosa, and Klebsiella sp. [17]. Moreover, functional components of smoke such as phenolics and acids had shown significant antimicrobial activities and some studies showed that carbonyl compounds and acids also own broad-spectrum antibacterial activities. Phenolic compounds also have antibacterial properties by interacting with bacteria cells through absorption through hydrogen bonding to inhibit bacterial activities in the cytoplasmic membrane [38].

The safety evaluation of smoke as a drying agent and preservative needs to be done since the presence of benzo[a]pyrene must be reduced as much as possible since this carcinogenic compound poses health risks to customers. Benzo[a]pyrene is a pro-carcinogenic 
compound and the enzymatic metabolism of such compounds would generate mutagenic benzo[a] pyrenedioleposida. Benzo[a]pyrene and benzo[a] anthracene compounds were generated from imperfect combustion of carbon-containing materials such as wood. This could be caused by the type of wood, the combustion process, and the amount of wood used during the process. Cinnamon wood smoke contains low benzo[a]pyrene content during the burning process. The higher the temperature and the longer the burning temperature, the tendency of benzo[a]pyrene formation will decline [8].

According to FAO and $\mathrm{WHO}$, the maximum content of benzo[a]pyrene is $10 \mu \mathrm{g} / \mathrm{kg}$ in food products while according to the Indonesian FDA regulation number HK.00.06.1.52.4011, the maximum content of benzo[a]pyrene in smoked fish is $5 \mathrm{ppb}$. Cinnamon wood produced a high-quality smoke with a low content of benzo[a]pyrene at $0.04 \mathrm{ppm}$ compared with the benzo[a]pyrene content of the smoke from coconut shell and fiber. Unlike the cinnamon wood smoke, the higher the combustion temperature, the content of benzo[a]pyrene tends to decline, so it is safe for food applications. All observed purification processes were found to be effective in removing benzo[a]pyrene from cinnamon liquid smoke to ensure its safety for use in food processing and as an alternate preservative by smoking [9].

\section{CONCLUSION}

This study showed that longer the smoking duration would result in kawa daun powder with lower moisture content and brewed kawa daun beverage with higher $\mathrm{pH}$, darker color, and stronger aroma and taste. Statistically speaking, 4-hour and 6-hour smoking treatment resulted in no significant difference in several analyses. The best kawa daun beverage was obtained by $6-$ hour smoking treatment with a moisture content of $3.04 \%$, $\mathrm{pH}$ of 6.63 , color at $\mathrm{L}^{*}=8.81, \mathrm{a}^{*}=8.43, \mathrm{~b}^{*}=-14.70$, and liking score of $4.19,4.39,4.25$ and 4.34 in terms of its color, aroma, taste, and overall liking respectively. 6-hour smoked kawa daun beverage had some advantages in terms of its brewed liquid color (black), the smell of dried kawa daun powder (fragrance), the aroma brewed kawa daun beverage, its unique taste and distinctive kawa daun flavor, as well as better astringency and softer bitter aftertaste compared to other treatments.

\section{ACKNOWLEDGMENT}

This article was presented to the author's beloved parents, my father Defrial and mother Ida Royani who continuously supported and prayed for the author, as well as the author's siblings who supported and cherished the author. Thank you very much to Dr. Nancy Dewi Yuliana and Dr. Nurheni Sri Palupi who gave tremendous moral and material support and provided instructions to the author along with the research. The author would also thank LPDP Scholarship who gave research funding to the author which helped the author finished the research successfully.

\section{REFERENCES}

[1] [AOAC] Analysis Association of Official Analytical Chemists, 'Determination of moisture, ash, protein, and fat', $18^{\text {th }}$ Edition., Washington DC, 2005.

[2] R.F. Almeida, C.M. Ulrich, R.W. Owen, and M.T.S Trevisan, 'Content and solvent extraction in coffee leaves from Brazil', Department of organic and inorganic chemistry, Ceará Federal University. Brazil, 2014.

[3] N. Andarwulan, K. Feri, and H. Dian, 'Analisis pangan', Dian Rakyat., Bogor, 2011.

[4] Anto, R. Rato, 'Effect of the addition cinnamon (Cinnamomum burmannii) powder on chemical and total microbial properties in chicken nugget', $J$. Agropolitan, vol. 5, no. 1, 2018.

[5] H. Ashihara, 'Metabolism of alkaloids in coffee plants', Braz. J. Plant Physiol., 18(1):1-8, 2006.

[6] M. Astawan, 'Khasiat warna-warni makanan', Gramedia Pustaka Utama., Jakarta, 2008.

[7] A.A. Bello, V.B. Palacios, P.G. Segovia, J.M. Bel, and J.M. Monzo, 'Effect of $\mathrm{pH}$ on color and texture of food products', Food Eng Rev., 5:158-170, 2013, doi: 10.1007/s12393-013-9067-2.

[8] I.K. Budaraga, Arnim, Y. Marlida, U. Bulanin, 'Characteristics of cinnamon liquid smoke produced using several purification techniques', AJFSN., 3(2): 16-21, ISSN: 2381-6228, 2016.

[9] I.K. Budaraga, Arnim, Y. Marlida, U. Bulanin, 'Liquid smoke production quality from raw materials variation and different pyrolysis temperature', IJASEIT., vol. 6, no. 3, ISSN: 2088-5334, 2016, doi : 10.18517/ijaseit.6.3.737.

[10] C. Campa, L. Mondolot, A. Rakotondravao, L.P.R. Bidel, A. Gargadennec, E. Couturon, P.L. Fisca, J. Rakotomalala, C. Jay-allemand, and A.P. Davis, 'A survey of mangiferin and hydroxycinnamic acid ester accumulation in coffee (Coffea) leaves: biological implications and uses', 595 - 613, 2012, doi:10.1093/aob/mcs119.

[11] A. Farida, E. Ristanti, A.C. Kumoro, 'Penurunan kadar kafein dan asam total pada biji kopi robusta menggunakan teknologi fermentasi anaerob fakultatif dengan mikroba nopkor MZ-15'. Jurnal Teknologi Kimia dan Industri., vol.2, no. 3, hal 70-75, 2013. 
[12] Y. Ferry, 'Prospek pengembangan kayu manis (Cinnamomum burmanii L) di Indonesia', SIRINOV., vol. 1, no 1, hal : 11 - 20, 2013.

[13] J.R.D. Finzer, A.T. Valduga, M.M.P. Ferreira, I.L. Goncalves, 'Beverages of coffee tree leaves', $J$. Anal Pharmaceut Res., vol. 7, Issue. 4. Chemical engineering, Uberaba University. Brazil, 2018.

[14] S. Fitriani, 'Pengaruh suhu dan lama pengeringan terhadap beberapa mutu manisan belimbing wuluh (Averrhooa bilimbi L) kering', Jurnal Sagu, Universitas Riau, vol. 7, no. 1, hal :3237, 2008.

[15] M.A. Fuferti, Syakbaniah, Ratnawulan, 'Perbandingan karakteristik fisis kopi luwak (civet coffee) dan kopi biasa jenis arabika', Pillar of physics., vol. 2, 68-75, 2013.

[16] S. Gokulakrishnan, K. Chandraraj, Gummadi, N. Sathyanarayana, 'Microbial and enzymatic methods for the removal of caffeine', Enzyme and Microbial Technology., 37 (2005) 225-232, 2005, doi: 10.1016/j.enzimictec.2005.03.004.

[17] Gupta, Charu, A.P. Garg, R.C. Uniyal, A. Kumari, 'Antimicrobial activity of some herbal oils againts common foodborne pathogens', AJMR., vol. 2, pp. 258-261, ISSN 19960808, 2008.

[18] A. Handayani, 'Application of defects value system in robusta coffee commodities (case study in Wonokerso, Pringsurat, Temanggung)', Jurnal Litbang Provinsi Jawa Tengah., vol. 11, no. 2, 2013.

[19] R. Hayati, A. Marliah, F. Rosita, 'Chemical characteristics and sensory evaluation of arabica coffee powder', J. Floratek., 7: 66-75, 2012.

[20] D. Indrasti, N. Andarwulan, E.H. Purnomo, N. Wulandari, 'Suji leaf chlorophyll: potential and challenges as natural colorant', JIPI., ISSN 08534217. EISSN 2443-3462, vol. 24 (2) : 109-116, 2019, doi: 10.18343/jipi.24.2.109.

[21] A. Kaemba, E. Suryanto, C.F. Mamuaja, 'Karakteristik fisiko-kimia dan aktivitas antioksidan beras analog dari sagu baruk (Arenga microcarpha) dan ubi jalar ungu (Ipomea batatas L. Poiret)', Jurnal Ilmu dan Teknologi Pangan., 5(1): 1-8, 2017.

[22] K. Khotimah, 'Karakteristik kimia kopi kawa dari berbagai umur helai daun kopi yang diproses dengan metode berbeda', J. Teknol. Pertan. 9(1):40-48, 2014.

[23] L.B.F. Lunkes and L.N. Hashizume, 'Evaluation of the $\mathrm{pH}$ and titratable acidity of teas commercially available in Brazilian market'. Revista Gaúcha de Odontologia 62(1): 59-64, 2014.

[24] K. Miazek, S. Ledakowicz, 'Chlorophyll extraction from leaves, needles and microalgae: a kinetic approach', IJABE., 6(2): 107-115, 2013.
[25] A. Monteiro, S. Colomban, H.G. Azinheira, L.G. Guimaraes, M.D.C. Silva, L. Navarini, M. Resmini, 'Dietary antioxidants in coffee leaves: impact of botanical origin and maturity on chlorogenic acids and xanthones', Journal of Antioxidants, 9, 6, 2019, doi: 10. 3390/ antiox 9010006.

[26] N. Nayeem, G. Denny, S.K. Mehta, 'Comparative phytochemical analysis, antimicrobial and anti oxidant activity of the methanolic extracts of the leaves of coffea arabica and coffea robusta', Der Pharm. Lett., 3(1):292-297, 2011.

[27] R. Novita, A. Eviza, J. Husni, S.K. Putri, 'Analisis organoleptik formula minuman kahwa daun mix', $J$. Teknol. Pertan. Andalas., 21 (1) : 58, 2017, doi:10.25077/jtpa.21.1.58-62.2017.

[28] R. Novita, A. Kasim, T. Anggraini, D.P. Putra, 'Kahwa daun: traditional knowledge of a coffee leaf herbal tea from West Sumatra, Indonesia', J. Ethn. Foods. 5 (November) : 1 -6, 2018, doi:10.1016/j.jef.2018.11.005.

[29] R. Novita, A. Kasim, T. Anggraini, D.P. Putra, 'Survei proses pembuatan minuman kahwa daun di Propinsi Sumatra Barat, Indonesia', Jurnal Teknologi Pertanian Andalas., vol. 22, no.1, ISSN 1410-1920, EISSN 2579-4019, 2018.

[30] G. Pumilia, M.J. Cichon, J.L. Cooperstone, D. Giuffrida, G. Dugo, S.J. Schwartz, 'Changes in chlorophylls, chlorophyll degradation products and lutein in pistachio kernels (Pistacia vera L.) during roasting', Food Research International., 65: 193-198, 2014, doi.org/10.1016/j.foodres.2014. 05.047.

[31] P.A. Putra, 'Profil tanah datar persada : kawa daun', Dokumen Kabupaten Tanah Datar, Provinsi Sumatra Barat, 2014.

[32] E. Rahayuningsih, M.S. Pamungkas, M. Olvianas, A.D.P. Putera, 'Chlorophyll extraction from suji leaf (Pleomele angustifolia Roxb.) with $\mathrm{ZnCl} 2$ stabilizer', JFST., $55 \quad$ (3): 1.028-1.036, 2018, doi.org/10.1007/s13197-0173016-7.

[33] S. Ratanamarno, S. Surbkar, 'Caffeine and catechins in fresh coffee leaf (Coffea arabica) and coffee leaf tea', Maejo international journal of science and technology, 11(3):211-218, 2017.

[34] Rif'an, Nurrahman, S. Aminah, 'The influence of kind of dryer instrument to physical characteristics, chemistry and organoleptic of pumpkin soup instant', Jurnal Pangan dan Gizi., 7 (2): 104-116, 2017.

[35] Shan, Bin, Y.Z. Cai, J.D. Brooks, H. Corke, 'The in vitro antibacterial activity of dietary spice and medicinal herb extracts', International Journal of Food Microbiology., 117 page 112-119, 2007. 
[36] F.H.T. Siringoringo, Z. Lubis, R.J. Nainggolan, 'Study of tea making from coffee leaves', J. Rekayasa Pangan dan Pert., vol. 1, no. 1, 2012.

[37] Syarief, R. Winny, 'Analisis farmasi', Terjemahan dari Watson, Pharmaceutical Analysis., Elsevier Limited. Oxford : United Kingdom, 2005.

[38] R.T. Toledo, 'Wood smoke components and functional properties', In: D.E. Kramer and L. Brown (eds.). International Smoked Seafood Conference Proceedings. Alaska Sea Grant College Program, Fairbanks, pp. 55-61, 2008 doi:10.4027/isscp.2008.12.
[39] X. Wang, C. Xu, M. Jaroniec, Y. Zheng, S.Z. Qiao, 'Anomalous hydrogen evolution behavior in high-pH environment induced by locally generated hydronium ions', Nature Communications., 10:4876, 2019, doi.org/10.1038/s41467-019-12773-7.

[40] F. Winarno, 'Kimia pangan dan gizi', Gramedia Pustaka Utama, Jakarta, 2002.

[41] Zed, Mestika, 'Dilema ekonomi melayu : dari melayu kopi daun hingga kapitalisme global', Innovation X (2): 209-23, 2011. 